\title{
Adaptive physiological and biochemical response of sugarcane genotypes to high-temperature stress
}

\author{
S. Kohila ${ }^{1} \cdot$ R. Gomathi ${ }^{1}$
}

Received: 27 October 2017/ Accepted: 23 March 2018/Published online: 12 April 2018

(C) The Author(s) 2018

\begin{abstract}
Impact of elevated temperature on physiological and biochemical changes were evaluated in 5 commercial sugarcane genotypes and 2 wild species clones at two different growth phases. The study revealed that heat stress decreased chlorophyll content, chlorophyll stability index (CSI), SPAD value, maximum quantum efficiency of PSII photochemistry $\left(\mathrm{F}_{\mathrm{v}} / \mathrm{F}_{\mathrm{m}}\right.$ ratio), leaf gas exchange parameters, relative water content (RWC), and activities of nitrate reductase (NR), sucrose-metabolizing enzymes (SPS, SS, AI, NI) in all the genotypes and species clones. In contrast, elevated temperature induced an increase in proline, total phenolics content (TP), antioxidant enzyme activities (SOD and POX), lipid peroxidation (LP), membrane injury index (MII) and soluble sugar content in all clones. Principal component analysis based on physiological heat tolerance indexes could clearly distinguish sugarcane genotypes into three heat tolerance clusters. Noteworthy in comparison to the heat-sensitive varieties, sugarcane genotype that possessed higher degrees of heat tolerance Co 99004 displayed higher chlorophyll content, CSI, antioxidant enzyme activities, NR activity, RWC, total phenols, sucrose-metabolizing enzymes, soluble sugar content and leaf gas exchange and lower level of lipid peroxidation and membrane injury index.
\end{abstract}

Keywords Elevated temperature $\cdot$ Chlorophyll $\cdot \mathrm{F}_{\mathrm{v}} / \mathrm{F}_{\mathrm{m}}$ ratio - Antioxidant enzyme - Sucrose metabolizing enzymes $\cdot$ Leaf gas exchange

R. Gomathi

gomathi_sbi@yahoo.co.in

1 Plant Physiology, ICAR-Sugarcane Breeding Institute, Coimbatore, Tamilnadu 641 007, India

\section{Introduction}

Sugarcane is an important industrial crop used for sugar and bio-energy. It is one of the world's major C4 crops that mainly grow in the tropic and sub-tropic regions. Weather and climate related events (i.e., growth environment of atmospheric $\left[\mathrm{CO}_{2}\right]$, temperature, precipitation, and other extreme weather) are the key factors for sugarcane production worldwide, especially in many developing countries (Zhao and Li 2015). The rise in temperature even by a single degree beyond the threshold level is considered as heat stress in plants (Hasanuzzaman et al. 2013). Increases in temperature may cause yield declines between $2.5 \%$ and $10 \%$ across a number of agronomic species throughout the twenty-first century (Hatfield et al. 2011). The unfavorable temperature may significantly affect photosynthesis, respiration, water balance, and membrane stability of leaves reported by Kaushal et al. (2016).

Chlorophyll fluorescence $\left(\mathrm{F}_{\mathrm{v}} / \mathrm{F}_{\mathrm{m}}\right.$ ratio $)$ has been suggested as quantitative measures of the photochemical efficiency of the PSII complex under different environmental stresses (Adams et al. 1990). Nitrate reductase (NR) involved in nitrogen metabolism, play important role in amino acid biosynthesis, and regulates the protein synthesis (Harris et al. 2000). Proline and soluble sugars is necessary to regulate osmotic activities and maintaining the cell water balance, membrane stability and by buffering the cellular redox potential (Farooq et al. 2008). Secondary metabolites such as phenolics play roles in abiotic stress responses generally associated with tolerance to heat (Wahid 2007). Sucrose synthesis is catalyzed by sucrose phosphate synthase (SPS), sucrose synthase (SS) and its degradation is catalyzed by invertase (Preiss 1982). Gomathi et al. (2017) reported in sugarcane that average reduction of SS and SPS activity were recorded at elevated 
temperature $\left(42{ }^{\circ} \mathrm{C}\right)$, While in tolerant variety SS and SPS activity was higher under elevated temperature. The ability to sustain leaf gas exchange [net photosynthesis $(P n)$, Stomatal conductance $(g s)$, transpiration rate and $\mathrm{CO}_{2}$ assimilation rates] under heat stress has a direct relationship with heat tolerance (Hall 1992). Oxidative stress can cause lipid peroxidation and consequently membrane injury, protein degradation, and enzyme inactivation (Meriga et al. 2004). The reactive oxygen species-scavenging enzymes, for example, ascorbic peroxidase, catalase, guaiacol peroxidase and superoxide dismutase are enhanced by heat stress (Chaitanya et al. 2002; Gomathi and Kohila 2016). Heat stress impairs mitochondrial functions thereby resulting in the induction of oxidative damage that manifests in lipid peroxidation, detected by malondialdehyde (MDA) content (Vacca et al. 2004).

Sugarcane production may have been negatively affected and will continue to be considerably affected by increases in the frequency and intensity of extreme environmental conditions due to climate change. The degree of climate change impact on sugarcane is associated with geographic location and adaptive capacity. However, there has been little research conducted to document these effects as found by Kumudini et al. (2014). Based on pot and field studies with intensive measurements of physiological, growth, and yield traits, we also found that some sugarcane genotypes are more tolerant to stress environment than others (Zhao et al. 2015). To our knowledge, heat stress in sugarcane has received much less attention than the other abiotic stresses. Sugarcane varietal evolution in the future requires yield stability even under harsh climates, understanding of the metabolic and molecular signal transcription processes and the interaction to high temperatures is absolutely necessary. Therefore, to screening new sugarcane cultivars tolerant to heat stress that can contribute to adaptation to climate change (especially for elevated $\mathrm{CO}_{2}$ and temperature) by discovering physiological screening technologies can mitigate the negative effect of climate change and improve sugarcane yields, productivity, and sustainability.

\section{Materials and methods}

A pot culture experiment (with confirmation trail) was conducted at Plant Physiology Section, Crop Production Division, ICAR-Sugarcane Breeding Institute, Coimbatore for selection of tolerant sugarcane genotype for high-temperature stress during 2016-2018. The seven sugarcane genotypes used in the present study includes five commercial canes (Co 06022, Co 0315, Co 8021, Co 86032 and Co 99004) and two wild sugarcanes (Spontaneum Spp.) genotypes (Taiwan -96 and SES -150). Two sets of pot culture experiment were contacted simultaneously, one for formative phase (150 days) and another one grand growth phase (210 days). The experiment laid out Completely Randomized Block Design with replication thrice. Normal recommended agronomic practices were performed for these experiments.

\section{Heat stress treatment}

In order to develop a study more applicable to field conditions, experimentally heat stressed sugarcane genotypes received a temperature $4-5{ }^{\circ} \mathrm{C}$ above its optimum temperature range, an increase which corresponds tightly to climate change model predictions. Control plants were grown under optimal conditions at $37 / 28 \pm 2{ }^{\circ} \mathrm{C}$ day/night with a 12-h photoperiod. Heat stressed plants were grown at $45 / 32 \pm 2{ }^{\circ} \mathrm{C}$ during the day/night with a 12 -h photoperiod and for a total of 15 days, with $60-70 \%$ relative humidity, and light intensity $395-410 \mu \mathrm{mol} \mathrm{m} \mathrm{m}^{-2} \mathrm{~s}^{-1}$.

\section{Quantitative analysis of pigment content}

Chlorophyll content was estimated by Witham et al. (1971) and the amount of chlorophyll content was calculated using the following equations: Chlorophyll ' $\mathrm{a}$ ' $=\left(12.7 \times \mathrm{A}_{663}\right)-\left(2.69 \times \mathrm{A}_{645}\right) \times(\mathrm{V} / 1000 \times \mathrm{W})$, Chlorophyll 'b' $=\left(22.9 \times \mathrm{A}_{645}\right)-\left(4.68 \times \mathrm{A}_{663}\right) \times(\mathrm{V} /$ $1000 \times \mathrm{W})$ and Total chlorophyll $=\left(20.2 \times \mathrm{A}_{645}\right)$ $+\left(8.02 \times \mathrm{A}_{663}\right) \times(\mathrm{V} / 1000 \times \mathrm{W})$. Chlorophyll Stability Index (CSI) was estimated by Koleyoras (1958) and the chlorophyll content variations between the control and treatment were calculated as CSI. SPAD values of leaves were recorded as described by Peng et al. (1993): using the chlorophyll meter (SPAD - 502, Soil Plant analysis Development Section, Minolta Camera Co. Ltd., Japan).

Chlorophyll fluorescence of the leaves was measured using chlorophyll fluorometer OS-30p (Opti-Sciences, Hudson, USA). The ratio $F_{V} / F_{M}$ issued to assess the quantum efficiency for photochemistry of PSII (Krause and Weis 1991; Oliveiram et al. 2002). Relative water content (RWC) was measured as described by Barrs and Weatherley (1962). RWC $=[($ fresh weight - dry weight $) /$ (turgid weight - dry weight) $] \times 100$. Leaf gas-exchange measurements, including the rate of net photosynthesis (An), stomatal conductance (gs), the rate of transpiration (E) and the intercellular $\mathrm{CO}_{2}$ concentration $(\mathrm{Ci})$, were made using a portable Li-6400 m (LI-COR Inc., Lincoln, NE, USA).

\section{Biochemical assays}

Nitrate reductase (NR) activity in leaf was done according to the procedure of Hageman and Hucklesby (1971) with 
slight modifications. The enzyme activity (NR) was expressed as $\mu$ mole $\mathrm{NO}_{2} \mathrm{~g}^{-1} \mathrm{fw} \mathrm{h}^{-1}$. Analysis of proline content was estimated by the modified procedure of Bates et al. (1973). It was estimated with reference to the calibration curve and expressed as $\mu \mathrm{g} \mathrm{g}^{-1}$ tissue FW. The total phenol content was determined by Malick and Singh (1980) and the concentration of phenols express as mg phenols $/ 1 \mathrm{~g}$ extract. Estimation of Sucrose-metabolizing enzymes: Sucrose phosphate synthase (SPS) and sucrose synthase (SS) activity were estimated by the method described by Hubbard et al. (1989). Acid and neutral invertases were assayed by Hatch and Glasziou (1963) method. The total soluble sugar was estimated by Anthrone method (DuBois et al. 1956). Determination of antioxidant enzymes activities: Superoxide Dismutase was conveniently assayed using a slightly modified procedure (Madamanchi et al. 1994) and originally described by Beauchamp and Fridovich (1971). The enzyme activity is expressed as $\min ^{-1} \mathrm{~g}^{-1}$. Calculation: (maximum absorbance - minimum absorbance) $\times 60 \times 2$. Peroxidase (POD) activity was estimated by the method of Putter (1974). The level of lipid peroxidation was measured by estimating malondialdehyde (MDA) content according to the method of Heath and Packer (1968). The concentration of MDA was calculated using its extinction coefficient of $155 \mathrm{~mm}^{-1} \mathrm{~cm}^{-1}$. Membrane injury index (MII) was determined by Deshmukh et al. (1991) recording the electrical conductivity of leaf leachates in double distilled water at 40 and $100{ }^{\circ} \mathrm{C}$. $\mathrm{MII}=\left(\mathrm{C}_{1} / \mathrm{C}_{2}\right) \times 100$.

\section{Statistical analysis}

The experiments were arranged in a completely randomized design with three replications. The data obtained were analyzed by ANOVA and all means were separated at the $P<0.05$ level using the LSD test. All calculations and data analyses were performed using the SPSS 16.0 for Windows software package. All the data obtained were converted to stress tolerance indexes before Pearson's correlation, principle component analysis (PCA) and cluster analyses. Stress tolerance index was defined as the observed value of a target trait under a given stress level divided by the mean value for that trait under the control (Zeng et al. 2002). Principle component analysis and Cluster analysis were performed using the XLSTAT.

\section{Results and discussion}

For evolving heat stress tolerant sugarcane genotypes, it is necessary to understand the basic information on physiological and metabolic changes and their interaction with genotypes taking place under heat stress condition. Plant responses to high temperatures are mediated by both their inherent ability to survive and their ability to acquire tolerance to heat stress. In the present study, biochemical characterization of five sugarcane genotypes and two $S$. spontaneum spp. were undertaken for differences in their response to heat stresses. Sugarcane crop in the field is frequently subjected to heat stresses that affect adversely their growth, development and productivity.

\section{Chlorophyll content and stability}

The efficacy of light captured to drive photosynthesis is strongly related to the chlorophyll concentration in the leaf. Heat stress had shown the adverse effect on chlorophyll content, chlorophyll stability index (CSI) and SPAD value of sugarcane genotypes at formative phase (FP) and grand growth phase (GGP) are presented in Tables 1 and 2. Under controlled condition, sugarcane genotypes Co 86032 (1.60 $\mathrm{mg} \mathrm{g}^{-1} \mathrm{FW}$ and 81.2) and Co 99004 (1.58 $\mathrm{mg} \mathrm{g}^{-1}$ FW and 81.0) had highest total chlorophyll content and CSI respectively. In the present study, when the crop was exposed to heat stress at $45 \pm 2{ }^{\circ} \mathrm{C}$, a significant decrease in chlorophyll content, CSI and SPAD value were observed in all the genotypes, suggesting structural damage to the chloroplast in sugarcane genotype due to the high-temperature. Under heat stress condition, higher level of total chlorophyll content, CSI and SPAD value were observed in tolerant genotypes Co 99004 (0.87 $\mathrm{mg} \mathrm{g}^{-1} \mathrm{FW}, 72.8$ and 32.8), SES 150 (0.77 $\mathrm{mg} \mathrm{g}^{-1} \mathrm{FW}, 65.5$ and 32.6) and Co 06022 (0.76 $\mathrm{mg} \mathrm{g}^{-1} \mathrm{FW}, 62.7$ and 30.0), respectively, at formative phase. Average decrease over the control was 15.22 and $15.14 \%$ for chlorophyll 'a', 26.18 and $25.61 \%$ for chlorophyll 'b' 18.07 and $17.87 \%$ for total chlorophyll and 28.0 and $27.5 \%$ for CSI and 19.7 and $18.8 \%$ for SPAD value at FP and GGP, respectively, due to high temperature stress.

According to the results of two growth stage of the sugarcane genotypes, the FP was the sensitive phase and reduction percentage was higher compared to the GGP. The above results clearly show that loss of chlorophyll is directly linked with heat stress in sugarcane genotypes. The change in chlorophyll contents was used to evaluate the influence of environmental stress on plant growth and yield. Among the genotypes stress tolerant index of chlorophyll content was higher in Co 99004 at both FP and GGP, respectively (Table 3 ). In this studies indicated that high chlorophyll concentrations are associated with improved crop yield in tolerant genotypes as reported early research in wheat by Verma et al. (2004). The reduction in chlorophyll content, CSI and SPAD value were found higher in heat susceptible genotypes (Co 0315) as compared to heat stress tolerant. The decrease in chlorophyll 'a', chlorophyll 'b', total chlorophyll, CSI and SPAD value in response to induced heat stress has also been reported 


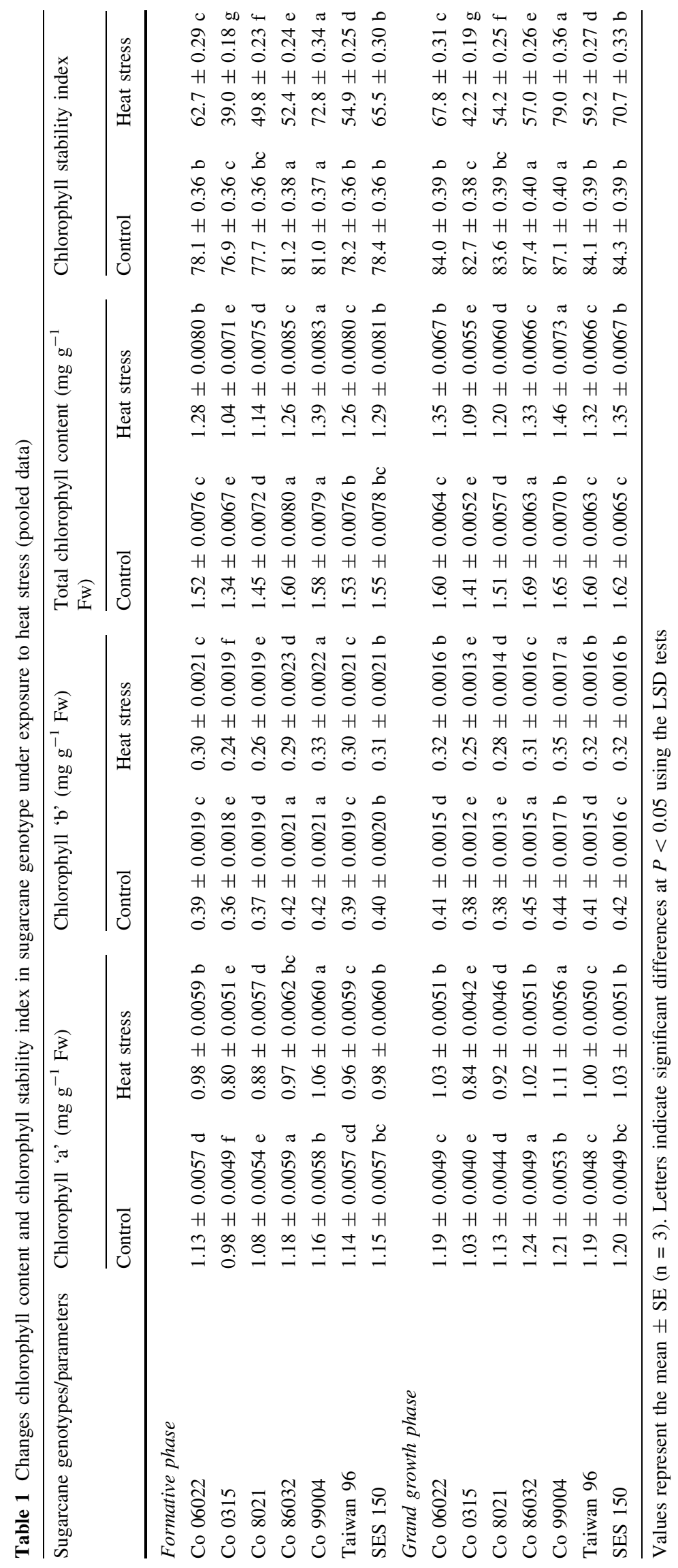




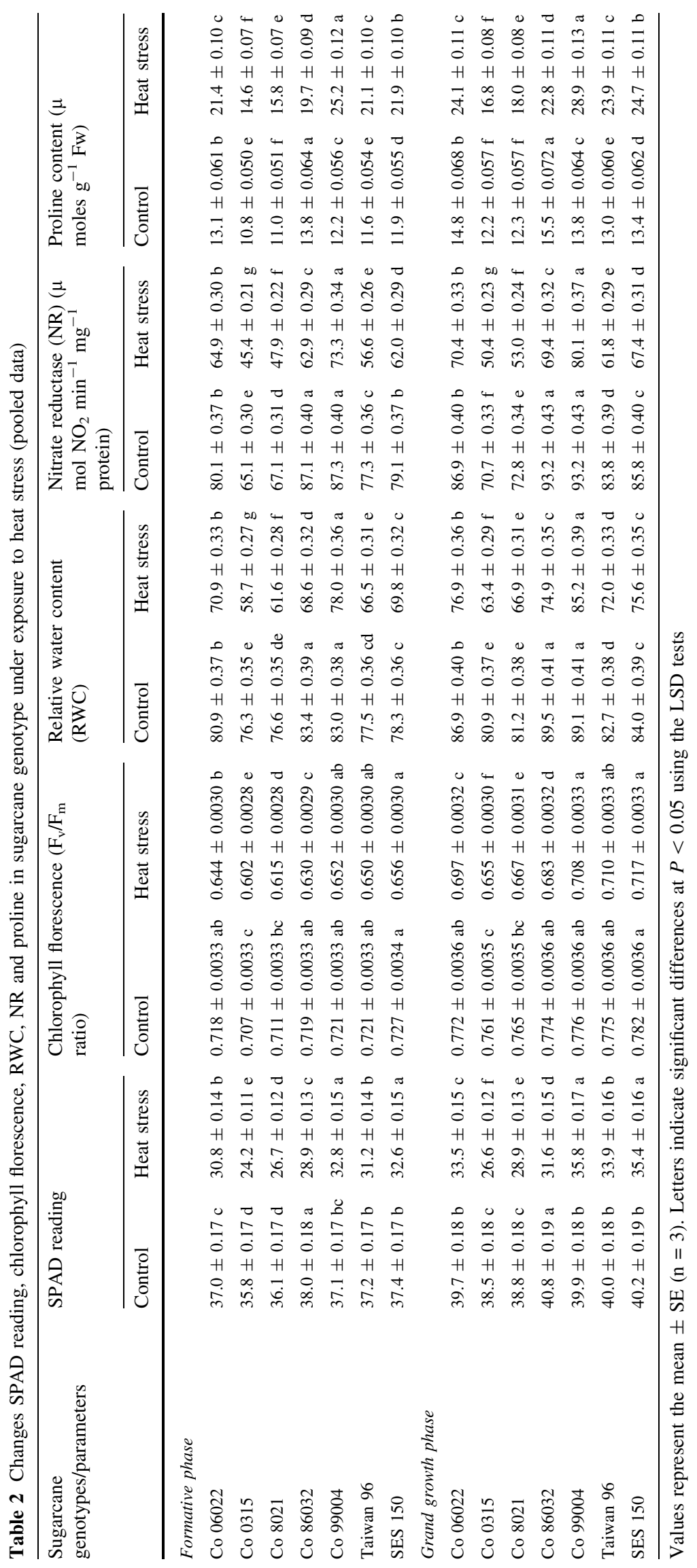


Table 3 Stress tolerant index (STI) for sugarcane genotype under exposure to heat stress at formative phase (FP) and grand growth phase (GGP) (pooled data)

\begin{tabular}{|c|c|c|c|c|c|c|c|c|c|c|c|c|c|c|}
\hline \multirow[t]{2}{*}{ Sugarcane genotypes/parameters } & \multicolumn{2}{|c|}{ Co 06022} & \multicolumn{2}{|c|}{ Co 0315} & \multicolumn{2}{|c|}{ Co 8021} & \multicolumn{2}{|c|}{ Co 86032} & \multicolumn{2}{|c|}{ Co 99004} & \multicolumn{2}{|c|}{ SES-91 } & \multicolumn{2}{|c|}{ SES-150 } \\
\hline & FP & GGP & FP & GGP & FP & GGP & FP & GGP & FP & GGP & FP & GGP & FP & GGF \\
\hline Chlorophyll 'a' & 0.86 & 0.87 & 0.81 & 0.82 & 0.81 & 0.81 & 0.82 & 0.82 & 0.91 & 0.92 & 0.84 & 0.84 & 0.85 & 0.86 \\
\hline Chlorophyll 'b' & 0.76 & 0.78 & 0.66 & 0.67 & 0.70 & 0.74 & 0.69 & 0.69 & 0.78 & 0.80 & 0.76 & 0.78 & 0.77 & 0.77 \\
\hline Total chlorophyll content & 0.84 & 0.84 & 0.77 & 0.77 & 0.78 & 0.79 & 0.78 & 0.79 & 0.88 & 0.88 & 0.82 & 0.83 & 0.83 & 0.83 \\
\hline Chlorophyll stability index & 0.80 & 0.81 & 0.51 & 0.51 & 0.64 & 0.65 & 0.65 & 0.65 & 0.90 & 0.91 & 0.70 & 0.70 & 0.84 & 0.84 \\
\hline SPAD reading & 0.83 & 0.84 & 0.68 & 0.69 & 0.74 & 0.75 & 0.76 & 0.77 & 0.88 & 0.90 & 0.84 & 0.85 & 0.87 & 0.88 \\
\hline Chlorophyll fluorescence & 0.90 & 0.90 & 0.85 & 0.86 & 0.86 & 0.87 & 0.88 & 0.88 & 0.90 & 0.91 & 0.90 & 0.92 & 0.90 & 0.92 \\
\hline roline content & 1.63 & 1.63 & 1.34 & 1.37 & 1.43 & 1.46 & 1.43 & 1.47 & 2.06 & 2.10 & 1.82 & 1.83 & 1.84 & 1.84 \\
\hline ter content & 0.88 & 0.89 & 0.77 & 0.78 & 0.80 & 0.82 & 0.82 & 0.84 & 0.94 & 0.96 & 0.86 & 0.87 & 0.89 & 0.90 \\
\hline Total phenol & 1.27 & 1.28 & 1.20 & 1.22 & 1.23 & 1.24 & 1.23 & 1.24 & 1.42 & 1.44 & 1.20 & 1.22 & 1.21 & 1.21 \\
\hline dismutase & 9 & 0.90 & 0.57 & 0.64 & 0.68 & 0.68 & 0.73 & 0.77 & 1.05 & 1.16 & 0.76 & 0.84 & 1.03 & 1.01 \\
\hline lase & 0.91 & 0.93 & 0.73 & 0.82 & 0.84 & 0.85 & 0.87 & 0.88 & 1.03 & 1.04 & 0.76 & 0.77 & 0.84 & 0.85 \\
\hline Lipid peroxidation & 1.19 & 1.18 & 1.67 & 1.67 & 1.39 & 1.36 & 1.28 & 1.27 & 1.09 & 1.07 & 1.08 & 1.05 & 1.07 & 1.04 \\
\hline Membrane injury index & 1.12 & 1.10 & 1.27 & 1.25 & 1.25 & 1.23 & 1.25 & 1.22 & 1.06 & 1.05 & 1.13 & 1.13 & 1.03 & 1.03 \\
\hline Nitrate reductase & 0.81 & 0.81 & 0.70 & 0.71 & 0.71 & 0.73 & 0.72 & 0.74 & 0.84 & 0.86 & 0.73 & 0.74 & 0.78 & 0.79 \\
\hline Sucrose phosphate synthase & 0.85 & 0.87 & 0.74 & 0.76 & 0.75 & 0.77 & 0.76 & 0.78 & 0.89 & 0.90 & 0.85 & 0.86 & 0.86 & 0.87 \\
\hline Sucrose synthase & 0.74 & 0.76 & 0.66 & 0.67 & 0.67 & 0.69 & 0.68 & 0.70 & 0.78 & 0.81 & 0.69 & 0.72 & 0.72 & 0.74 \\
\hline Acid invertase & 0.81 & 0.83 & 0.63 & 0.66 & 0.69 & 0.72 & 0.75 & 0.77 & 0.89 & 0.91 & 0.69 & 0.73 & 0.71 & 0.74 \\
\hline Neutral invertase & 0.80 & 0.82 & 0.58 & 0.63 & 0.60 & 0.67 & 0.66 & 0.70 & 0.87 & 0.91 & 0.75 & 0.77 & 0.82 & 0.85 \\
\hline Soluble sugar content & 1.30 & 1.32 & 1.10 & 1.12 & 1.11 & 1.13 & 1.13 & 1.17 & 1.36 & 1.36 & 1.10 & 1.11 & 1.11 & 1.11 \\
\hline Photosynthetic rate & 0.55 & 0.71 & 0.43 & 0.54 & 0.44 & 0.54 & 0.45 & 0.55 & 0.60 & 0.80 & 0.35 & 0.53 & 0.36 & 0.60 \\
\hline Stomatal conductance & 0.89 & 0.91 & 0.74 & 0.78 & 0.76 & 0.81 & 0.77 & 0.81 & 0.95 & 0.97 & 0.71 & 0.76 & 0.77 & 0.82 \\
\hline Transpiration rate & 0.76 & 0.77 & 0.70 & 0.70 & 0.71 & 0.71 & 0.71 & 0.72 & 0.83 & 0.86 & 0.66 & 0.67 & 0.74 & 0.74 \\
\hline Intercellular $\mathrm{CO}_{2}$ concentration & 0.81 & 0.82 & 0.69 & 0.71 & 0.71 & 0.73 & 0.73 & 0.74 & 0.86 & 0.88 & 0.66 & 0.68 & 0.71 & 0.72 \\
\hline
\end{tabular}

Stress tolerance index was defined as the observations under heat stress divided by the means of the controls

previously by Gosavi et al. (2014) in sorghum, Kumar et al. (2012b) in maize and rice.

\section{Chlorophyll fluorescence}

The ratio of $\mathrm{F}_{\mathrm{v}} / \mathrm{F}_{\mathrm{m}}$ is an important parameter describing the physiological state of photosynthesis organelle and serve as an indicator showing the activity of photosynthesis through the evaluation of release amount of chlorophyll fluorescence. A significant decreased in chlorophyll fluorescence $\left(\mathrm{F}_{\mathrm{v}} / \mathrm{F}_{\mathrm{m}}\right.$ ratio) was observed in sugarcane of all the genotypes subjected to the crop was exposed to heat stress (Table 2). Under heat stress condition, the highest $\mathrm{F}_{\mathrm{v}} / \mathrm{F}_{\mathrm{m}}$ ratio was observed in tolerant SES 150 (0.656 and 0.717), Co 99004 (0.652 and 0. 708) and Co 06022 (0.644 and 0.697 ) genotypes at FP and GGP, respectively. Average $\mathrm{F}_{\mathrm{v}} /$ $\mathrm{F}_{\mathrm{m}}$ ratio decrease over the control was 11.4 and $10.5 \%$ at formative and grand growth phase respectively. Among the genotypes stress tolerant index was higher in Co 99004 (0.90 and 0.91) and it range $0.85-0.90$ and $0.86-0.92$ at FP and GGP, respectively (Table 3). The results obtained in the present investigation are concomitant with the earlier reported by Cui et al. (2006). However, under heat stress, the conduction of PSII electrons is affected so as to lower the ratio of $\mathrm{F}_{\mathrm{v}} / \mathrm{F}_{\mathrm{m}}$. The reduction in $\mathrm{F}_{\mathrm{v}} / \mathrm{F}_{\mathrm{m}}$ ratio was mainly due to a decrease in the variable fluorescence at higher temperatures, which could be due to inefficient energy transfer from the light-harvesting $\mathrm{Chl} \mathrm{a} / \mathrm{b}$ complex to the reaction center (Briantais et al. 1986).

\section{Relative water content (RWC)}

Leaf RWC is a reliable indicator of leaf water deficit status at the time of sampling. It is often used to examine the response of a plant stress. Tolerant genotypes of Co 99004 , Co 06022 and SES-150 were able to maintain relatively high leaf RWC of 78.0, 70.0 and 69.8, respectively (Table 2), when subjected to heat stress, while sensitive genotype of Co 0315 showed the highest fold decrease of RWC over the control was observed 23.1 and $21.7 \%$ at FP 
and GGP, respectively, compared to rest of the genotypes at FP (Table 4). Similar result was reported in maize by Chen et al. (2012). Average decrease RWC over the control was 14.7 and $13.4 \%$ at FP and GGP respectively. The stress tolerance index of RWC at FP and GGP ranged from 0.77 to 0.94 and $0.78-0.96$, respectively (Table 3 ). The decrease RWC in response to induced heat stress has also been reported previously in Lotus creticus (Anon et al. 2004) and tomato (Morales et al. 2003).

\section{Nitrate reductase (NR)}

Nitrate reductase (NR) is the enzyme, which is involved in nitrogen metabolism, play important role in amino acid biosynthesis, and regulates the protein synthesis. NR activity of sugarcane genotypes at FP and GGP was determined and the result obtained is shown in Table 2. In the present study, the variability in terms of NR activity existed at different genotypes under heat stress, the highest NR activity under heat stress condition was observed significantly in tolerant genotypes Co $99004\left(73.3 \mu \mathrm{mol} \mathrm{NO}_{2}\right.$ $\mathrm{min}^{-1} \mathrm{mg}^{-1}$ protein) and $\mathrm{Co} 06022\left(64.9 \mu \mathrm{mol} \mathrm{NO} \mathrm{N}_{2}\right.$ $\min ^{-1} \mathrm{mg}^{-1}$ protein) and while the lowest NR activity was recorded in Co $0315\left(45.4 \mu \mathrm{mol} \mathrm{NO} \mathrm{min}^{-1} \mathrm{mg}^{-1}\right.$ protein). The mean NR activity, $\%$ fold decreased in over the control was lower in heat tolerant genotypes (Co 99004) $15.95 \%$, (Co 06022) 19.02\% and it decreased fold \% higher in susceptible genotypes (Co 0315) $30.38 \%$ at FP (Table 4). The similar trend was notified at grand growth phase. The average decrease in the control was 24.0 and $22.8 \%$ for NR activity at FP and GGP respectively, due to high-temperature stress. Among the genotypes stress tolerant index was higher in Co 99004 (0.84 and 0.86) and it range $0.70-0.84$ and $0.71-0.86$ at FP and GGP, respectively (Table 3). Hayat et al. (2009) has also reported in mustard that NR activity decreased in heat stressed plants serves as a biochemical adaptation to conserve energy by stopping nitrate assimilation at the initial stage. Haba et al. (2013) also recently stated that the activity of NR decreased in leaves exposed to high temperature in sunflower.

\section{Proline accumulation}

Proline accumulation is another well-known mechanism that has been evolved to cope with heat stress in a number of plant species. In this study, heat stress obviously induced a marked increase in proline accumulation relative to the level of the control (Table 2). It is interesting to note that higher folding $\%$ of proline accumulation in stress tolerant sugarcane cultivars of Co 99004 $\left(25.5 \mu \mathrm{mol} \mathrm{g}^{-1} \mathrm{fw}\right)$, SES-150 $\left(21.9 \mu \mathrm{mol} \mathrm{g}^{-1} \mathrm{fw}\right)$ and Co $06022\left(21.4 \mu \mathrm{mol} \mathrm{g}^{-1} \mathrm{fw}\right)$ were $106,83.5$ and $62.8 \%$ folds over control respectively (Table 4). The lowest proline content was recorded in Co $0315\left(17.8 \mu \mathrm{mol} \mathrm{g}{ }^{-1}\right.$ fw) at FP subjected to heat stress and the trend was found to be similar at GGP of the crop. The results obtained in the present investigation are concomitant with the earlier reported by Kumar et al. (2012a, b) in wheat. The stress tolerance index of proline accumulation among the sugarcane cultivars examined. It ranged from 1.34 to 2.06 and $1.37-2.10$ at FP and GGP, respectively. The higher stress tolerance index 2.06 and 2.10 was recorded in stress tolerant sugarcane Co 99004 genotype at FP and GGP, respectively (Table 3). Proline was accumulated under heat stress could also act as low mol. Wt. chaperones, stabilizing and protecting the structure of enzymes and proteins, maintaining membrane integrity and scavenging ROS, and a reservoir of nitrogen and carbon source for post stress growth (Hameed et al. 2012).

\section{Total phenols (TP)}

Enhanced synthesis of secondary metabolites under heat stress conditions also protects against oxidative damage. In the present study, the highest accumulation of total phenols (TP) under heat stressed condition was observed in tolerant genotypes Co 99004 and Co 06022 (732 and $636 \mu \mathrm{g} \mathrm{g}^{-1}$ FW), respectively, while the lowest phenols content was recorded in Co $0315\left(555 \mathrm{~g}^{-1} \mathrm{FW}\right)$ and in both wild sugarcane genotypes at FP (Table 5). Wahid and Ghazanfar (2006) also reported earlier that enhanced synthesis of total phenolics has been directly correlated with heat tolerance of sugarcane. The mean fold increase in TP accumulation over control was higher in stress tolerant Co 99004 (42.3\%) followed by Co $06022(27.2 \%)$ and heat stress susceptible Co 0315 (20.4\%) (Table 4). The stress tolerance index of total phenols activity at FP and GGP ranged from 1.20 to 1.42 and 1.21-1.44, respectively (Table 3 ). However, better accumulation of phenolics in tolerant variety may be related to better protection against oxidative damage, screening of harmful radiations, stabilization of sub-cellular structures and improvement in cell water balance as previously reported in Oenothera biensis by Fardus et al. (2014).

\section{Antioxidant enzyme activities}

The coordinate function of antioxidant enzymes like Superoxide Dismutase (SOD) and Peroxidase (POD) helps in the processing of reactive oxygen species (ROS) and regeneration of redox ascorbate and glutathione metabolites (Foyer and Nector 2000). In the present study, the heat stressed sugarcane genotypes exhibited a decreased in the activity of SOD and POD over the control in all genotypes, except heat tolerant genotype Co 99004. Under heat stress 


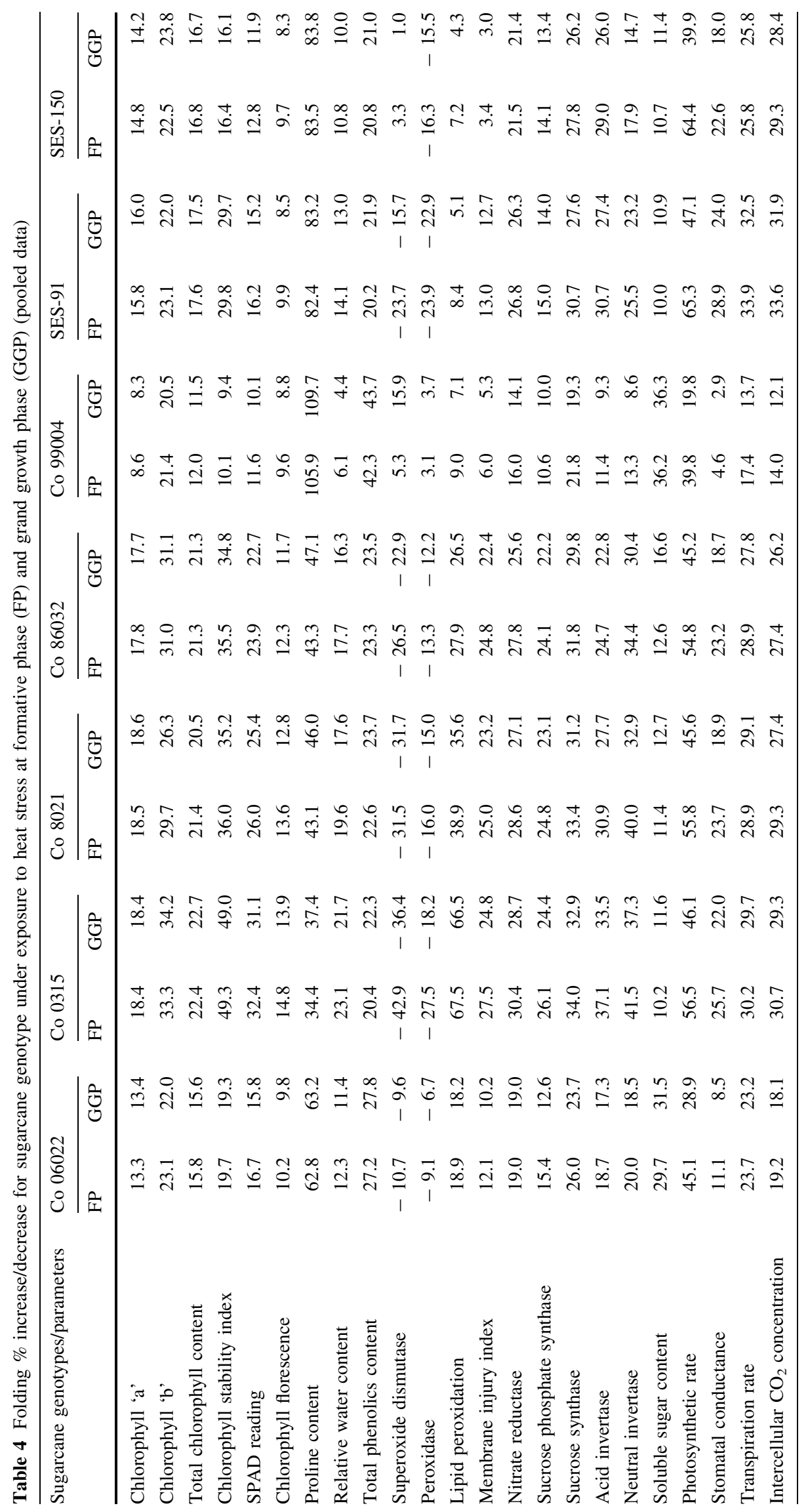




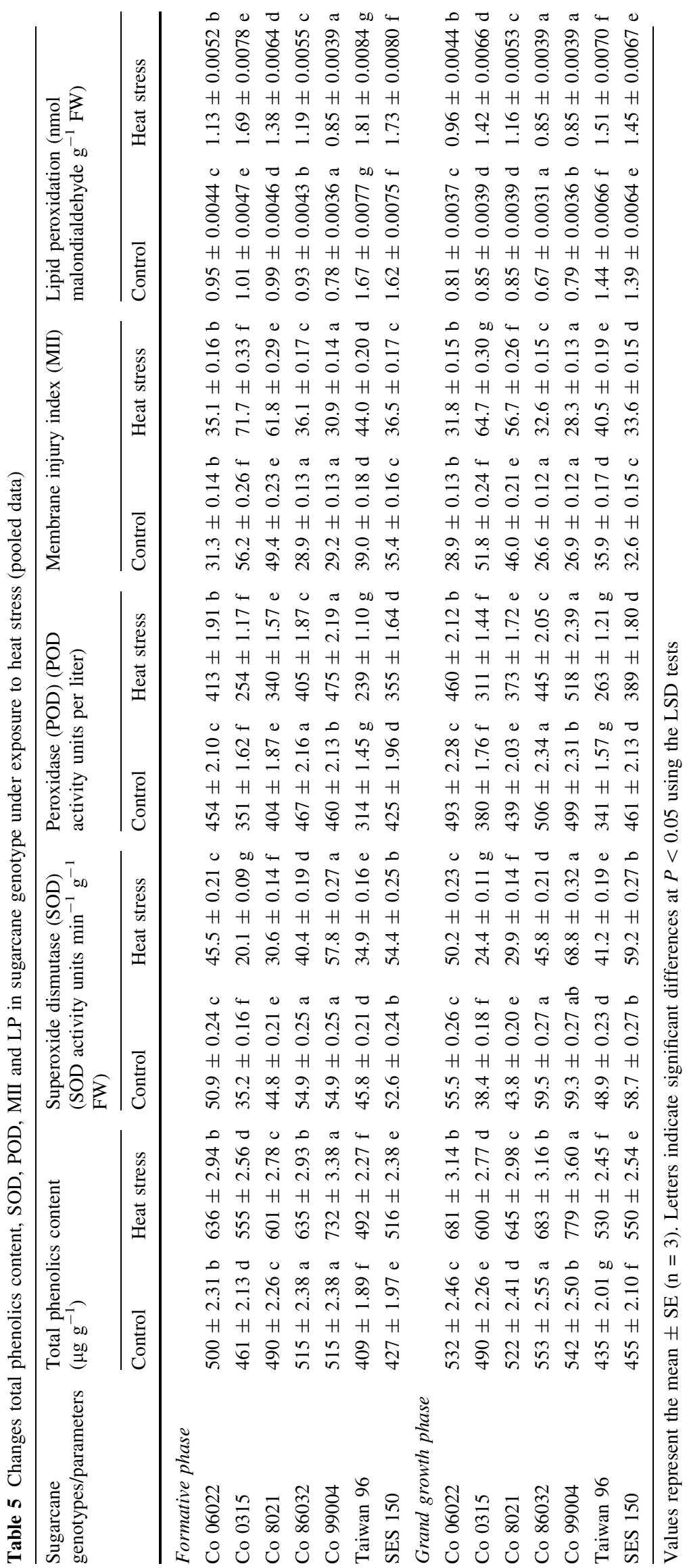


condition, Co 99004 led to the significantly highest SOD and POD activity of 57.8 and 68.8 Units $\mathrm{min}^{-1} \mathrm{~g}^{-1}$ fw of tissue and 475 and 518 Units per liter at FP and GGP, respectively, suggesting that high temperature could trigger antioxidant enzymes to scavenge ROS to counteract the injurious effect of ROS. Therefore, tolerance to high-temperature stress in crop plants to be associated with an increase in antioxidant activity has been found in agreement with earlier reported in sorghum (Gosavi et al. 2014) and in sugarcane (Gomathi and Kohila 2016). Whereas, SOD and POD activity of Co 0315 susceptible genotype was recorded comparatively less at both stages (Table 5). The ROS activity was found to be higher in Co 99004 under stress (5.3 and 15.9 and 3.1 and $3.7 \%$ at FP and GGP, respectively) compared to rest of the genotypes (Table 4) which was reflected in stress tolerance index (Table 3). When ROS increase; chain reactions start in which superoxide dismutase, a metallo-enzyme catalyses the dismutation $\mathrm{O}_{2}{ }^{-}$radical to molecular $\mathrm{O}_{2}$ and $\mathrm{H}_{2} \mathrm{O}_{2}$ reported in wheat by Kumar et al. (2012a) and peroxidases regulate the relatively stable levels of $\mathrm{H}_{2} \mathrm{O}_{2}$ to water and oxygen molecule reported in Mullberry by Chaitanya et al. (2002).

\section{Lipid peroxidation (LPO) and membrane injury index (MII)}

Lipid peroxidation is a natural metabolic process under normal aerobic conditions and it is one of the most investigated consequences of ROS action on membrane structure and function (Blokhina et al. 2003). Lipid peroxidation is a commonly utilized stress indicator of membrane damage (Taulavuori et al. 2001). In the present study, Lipid peroxidation (LPO) as malondialdehyde (MDA) content $0.85 \mathrm{n} \mathrm{mol} \mathrm{MDA} \mathrm{g}{ }^{-1} \mathrm{fw}$. and membrane injury index (MII) 30.9 were lower under heat stressed condition was observed in tolerant genotype Co 99004, while the highest LPO and MII of was recorded in Taiwan 96, SES-150 and Co 0315 at FP and GGP (Table 5). Earlier researchers reported that the relative tolerance of genotype to heat stress as reflected by its lower LPO, higher membrane stability, maintenance of high $\mathrm{f}_{\mathrm{v}} / \mathrm{f}_{\mathrm{m}}$ ratio and pigment concentration is related to the levels of activity of its antioxidant enzymes in sugarcane (Abbas et al. 2013). Also, Zhao et al. (2010) found in opium poppy that when the antioxidant enzyme activities were high, MDA content, as well as relative membrane LPO was low. Gomathi et al. (2013) reported in sugarcane that crop exposure to hightemperature caused a significant increase in lipid peroxidation (MDA content) and cell membrane injury. Average LPO and MII increased over the control were 23.1 and 20.4 and 17.4 and $15.8 \%$ at FP and GGP respectively, due to high-temperature stress. The stress tolerant index of LPO and MII were higher in heat tolerant genotype of Co 99004 compare to other genotypes (Table 3).

\section{Sucrose-metabolizing enzymes}

Many enzymes in internodes were related to sucrose metabolism, such as invertase, sucrose synthase (SS) and sucrose-phosphate synthase (SPS). Invertases cleave sucrose to glucose and fructose. Sucrose synthase can either cleave sucrose to UDP-glucose and fructose or catalyse the reverse, synthetic reaction. SPS synthesizes sucrose-6-phosphate reported in sugarcane by Gayler and Glasziou (1972). High temperature stress altered the activities of sucrose-metabolizing enzymes (SPS, SS, AI and NI) in sugarcane genotypes. When the crop were exposed to heat stress at $45 \pm 2{ }^{\circ} \mathrm{C}$, a significant decrease in sucrose-metabolizing enzymes were observed in all genotypes (Table 6). Heat stress tolerant genotypes had significantly highest activity of sucrose-metabolizing enzymes were observed in tolerant Co 99004 (29.8, 31.1, 27.7 and $36.3 \mu \mathrm{mol} \mathrm{g} \mathrm{fr} \mathrm{wt}{ }^{-1} \mathrm{~h}^{-1}$ ) and followed by Co $06022\left(26.3,27.8,24.0\right.$ and $30.6 \mu \mathrm{mol} \mathrm{g}$ fr $\mathrm{wt}^{-1} \mathrm{~h}^{-1}$ ) genotypes at FP as compared to susceptible genotypes, respectively. The similar trend was observed in GGP. Average decrease over the control was 18.7 and $17.2 \%$ for SPS, 29.2 and $27.1 \%$ for SS, 25.7 and $23.1 \%$ for AI and 27.7 and $23.6 \%$ for NI at FP and GGP respectively, due to high temperature stress. The maximum reduction in sucrose-metabolizing enzymes on account of heat stress was observed in Co 0315 and wild genotypes (Table 4). The higher stress tolerance index of SPS, SS, AI and NI $(0.89,0.78,0.89$ and 0.87$)$ were recorded in tolerant variety Co 99004 at FP, respectively (Table 3). Miguel et al. (2007) reported in tomato that the ability of plants to synthesize and accumulate sucrose in leaves under environmental stress is mainly determined by the concerted action of sucrose metabolizing enzymes. At low concentrations sucrose acts as signaling molecule while it has been suggested that in high concentrations it becomes an ROS scavenger reported in Arabidopsis by Sugio et al. (2009). However, Ebrahim et al. (1998) also thought the activities of sucrose-metabolizing enzymes decreased in sugarcane leaves under high-temperature stress accompanied with the sucrose content reduced.

\section{Total soluble sugar content (TSS)}

Total soluble sugars were increased under heat stress for oxidative adjustment. Data herein in Table 6 showed that all studied sugarcane genotypes TSS varied significantly between 46.2 and $71.0 \mu \mathrm{g} \mathrm{g}^{-1} \mathrm{fw}$ in non-stressed plant, while heat stress accumulated sugar contents under stress condition ranging from 50.8 to $96.7 \mu \mathrm{g} \mathrm{g}^{-1}$ fw at FP. It 


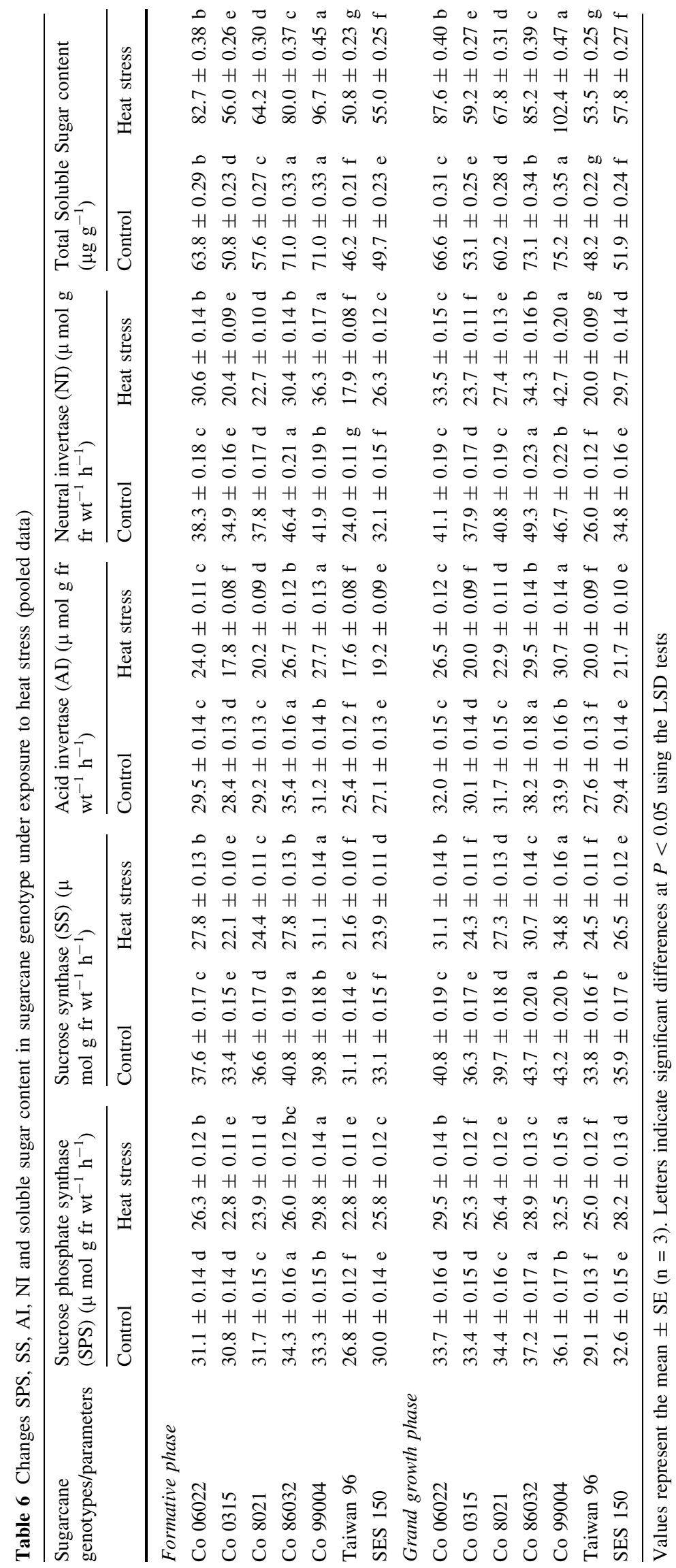


was noticed that total sugar content was enhanced under heat stress condition in sugarcane genotypes, maximum and minimum folding $\%$ increment were observed in Co 99004 (36.0\%) and Co 0315 (10.0\%), respectively (Table 4). Theses increases in total sugars in the tolerant genotypes may be due to inhibition of sucrose synthase or invertase activities as reported by Mohamed and AbdelHamid (2013) in cotton. In present study, heat stress showed an average increase of 18.4 and $19.9 \%$ for total sugars content at FP and GGP respectively. The higher stress tolerance index of 1.36 was recorded in tolerant variety Co 99004 at FP (Table 3). Under stress situation, TSS content was comparatively higher at GGP compared to FP. Hassanein et al. (2012) also reported in fenugreek that the increase in TSS may be acting as an adaptive mechanism for exerting protective effects under heat stress.

\section{Leaf gas exchange}

Leaf gas exchange is considered as one of the indicators to evaluate plants ability under different environment stress condition. Leaf gas exchange measurements including photosynthesis rate $\left(A_{n}\right)$, stomatal conductance $\left(g_{s}\right)$, transpiration rate $(\mathrm{T})$ and intercellular $\mathrm{CO}_{2}$ concentration $\left(\mathrm{C}_{\mathrm{i}}\right)$ were observed on sugarcane genotypes. In the present study, irrespective of varieties and wild species clones, when plant was exposed to heat stress a notable reduction in leaf gas exchange was observed over the control (Table 7). Under heat stress condition, significantly highest photosynthesis rate $\left(\mathrm{A}_{\mathrm{n}}\right)\left(11.44 \mu \mathrm{mol} \mathrm{CO} \mathrm{m}^{-2} \mathrm{~s}^{-1}\right)$, stomatal conductance $\left(\mathrm{g}_{\mathrm{s}}\right)\left(1.30 \mathrm{~mol} \mathrm{H}_{2} \mathrm{O} \mathrm{m}^{-2} \mathrm{~s}^{-1}\right)$, transpiration rate $(\mathrm{T})\left(10.83 \mathrm{mmol} \mathrm{H}_{2} \mathrm{O} \mathrm{m}^{-2} \mathrm{~s}^{-1}\right)$ and intercellular $\mathrm{CO}_{2}$ concentration $\left(\mathrm{C}_{\mathrm{i}}\right)\left(320 \mu \mathrm{mol} \mathrm{CO} \mathrm{CO}_{2} \mathrm{~m}^{-2} \mathrm{~s}^{-1}\right)$ were observed in stress tolerant Co 99004 followed by Co 06022 and Co 86032 genotypes, respectively, and the maximum reduction in leaf gas exchange on account of heat stress was observed in Co 0315 at FP. The similar trend was observed in GGP. The average decrease over the control was 52.6 and $37.1 \%$ for photosynthesis rate, 19.1 and $15.2 \%$ for stomatal conductance, 26.7 and $25.7 \%$ for transpiration rate and 25.9 and $26.4 \%$ for intercellular $\mathrm{CO}_{2}$ concentration at FP and GGP respectively. Among the varieties, Co 99004 attained the highest stress tolerant index (Table 3) at both FP and GGP. Unlike other environmental stresses, in the present study varieties which transpire more water under elevated temperature condition could maintain transpiration cooling and RWC and their by higher photosynthetic rate compared less transpiring varieties. However, some earlier researchers reported that high temperature stress reduces net photosynthetic rate, stomatal conductance in sunflower (Haba et al. 2013), and transpiration of water and $\mathrm{CO}_{2}$ diffusion into the leaf tissues in rice (Sikuku et al. 2010). The results of two growths stage of the sugarcane genotypes, FP was sensitive stage and reduction percentage of leaf gas exchange was higher compared to GGP.

\section{Principle component (PC) analysis}

Loading plots of principle component 1 and 2 analysis obtained from physiological data of seven sugarcane genotypes subjected to heat stress are illustrated in Fig. 1. PCA in the current study allowed for easy visualization of complex data and the physiological parameters among seven sugarcane genotypes were separated by PC1 and PC2. In this study, principle component 1 (PC1) describes $79.01 \%$ of the original information and principal component 2 ( $\mathrm{PC} 2$ ) describes $16.49 \%$. The cumulative percentage of $\mathrm{PC} 1$ and $\mathrm{PC} 2$ was $95.50 \%$ (Fig. 1). To investigate the contributors to the principle component, the physiological loadings in PC1 and PC2 were compared. It was clear that the, AN, CI, T, GS, TSS, POD, AI, SS, NR and CHL A were grouped together with positive loading on the right upper side of the biplot, suggesting that these parameters had a high positive correlation among themselves. Total CHL, CSI, SOD, RWC, NI, CHL B, SPAD, SPS, PRO and CHL FLU were observed on the right lower side of the biplot signifying that these parameters had a positive correlation among themselves. While LP and MII were found on the left upper portion of the biplot suggesting that these parameters had a highly negative and significant correlation among themselves.

Among the seven genotypes, Co 99004 and Co 06022 were grouped together with positive loading on the right upper side of the biplot, suggesting that this genotype found to tolerant with high-temperature stress. The species SES-150 is being grouped right lower portion of the biplot, indicating moderately tolerant to heat stress. While, Co 0315 Co 8021 and Co 86032 were grouped in a left upper portion of the biplot, and Taiwan-96 left lower portion of the biplot suggesting that these genotypes were sensitive to heat stress.

\section{Hierarchical cluster analysis (HCA)}

Hierarchical cluster analysis (HCA) was applied to search for classifiers (Fig. 2). The seven sugarcane cultivars were classified into three main clusters. Cluster I represented the heat sensitive group, with considered Co 0315, Co 8021 and Co 86032. Among the heat sensitive genotypes, Co 0315 similarity with 8.93 to other heat sensitive genotypes. Co 8031 with similar with 1.31 to Co 86032 . Cluster II represented that heat tolerant group, with considered Co 99004 and Co 06022. Co 06022 similar to Co 99004 with 12.37 similarities. Cluster III represented the heat tolerant as wild sugarcane genotype, with considered SES-150 and 


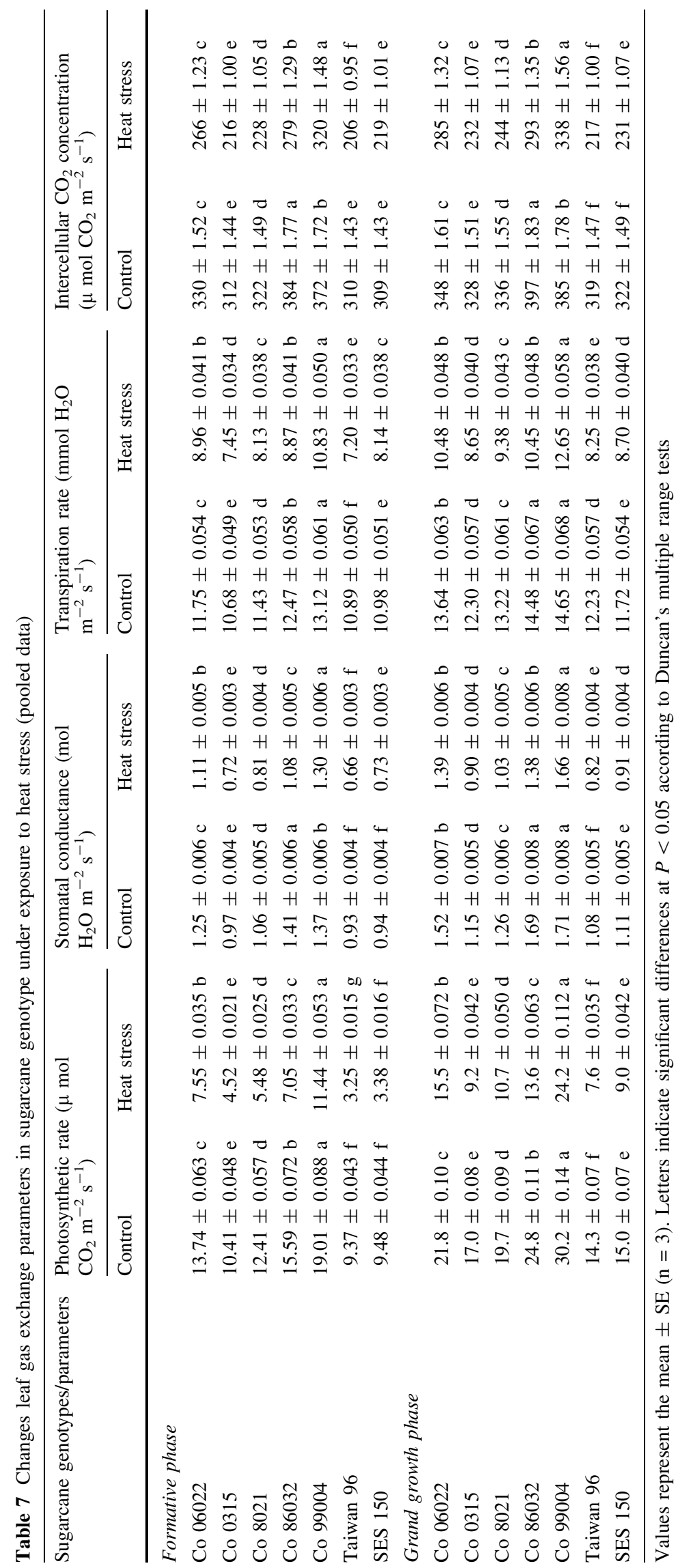


Fig. 1 Loading plots of principle components 1 and 2 of the PCA results obtained from physiological data of seven sugarcane cultivars subjected to heat stress

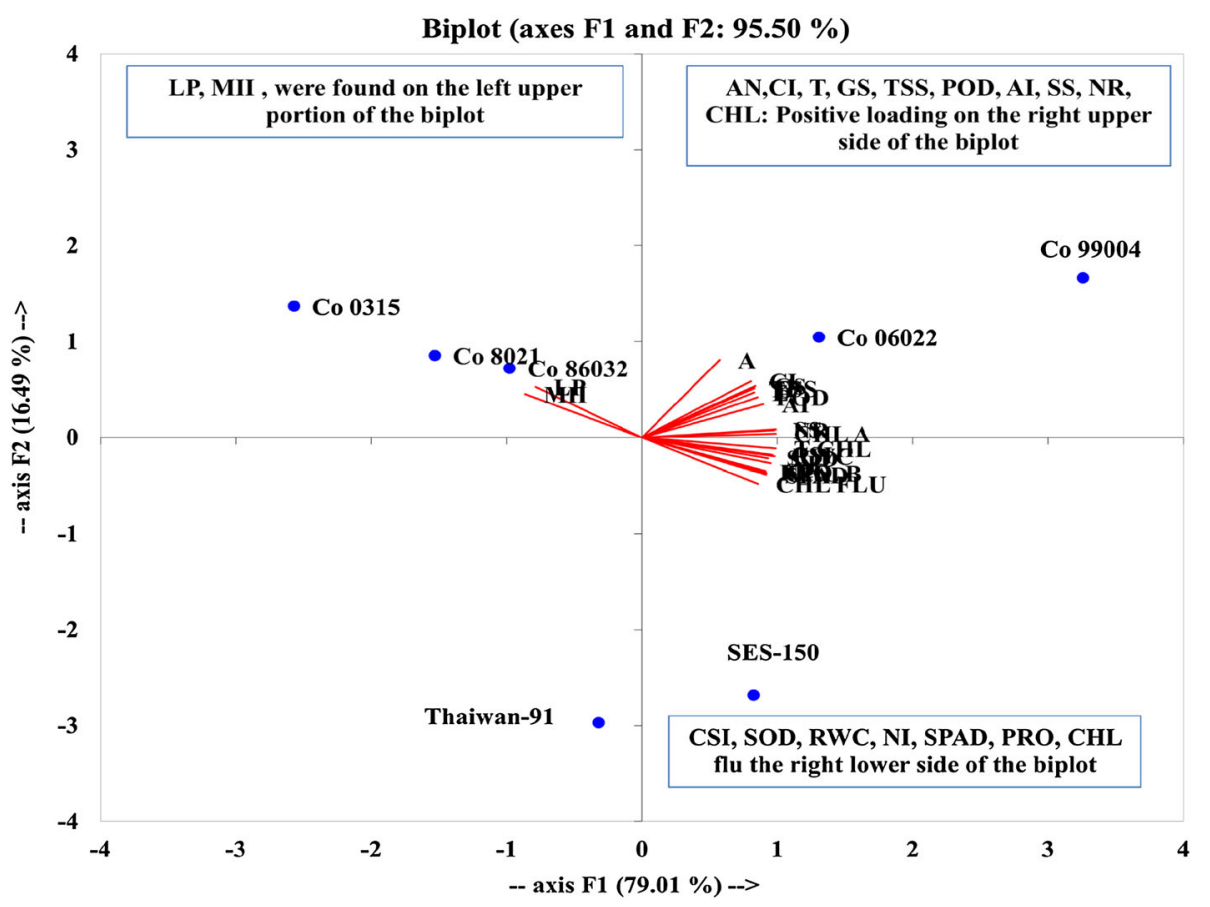

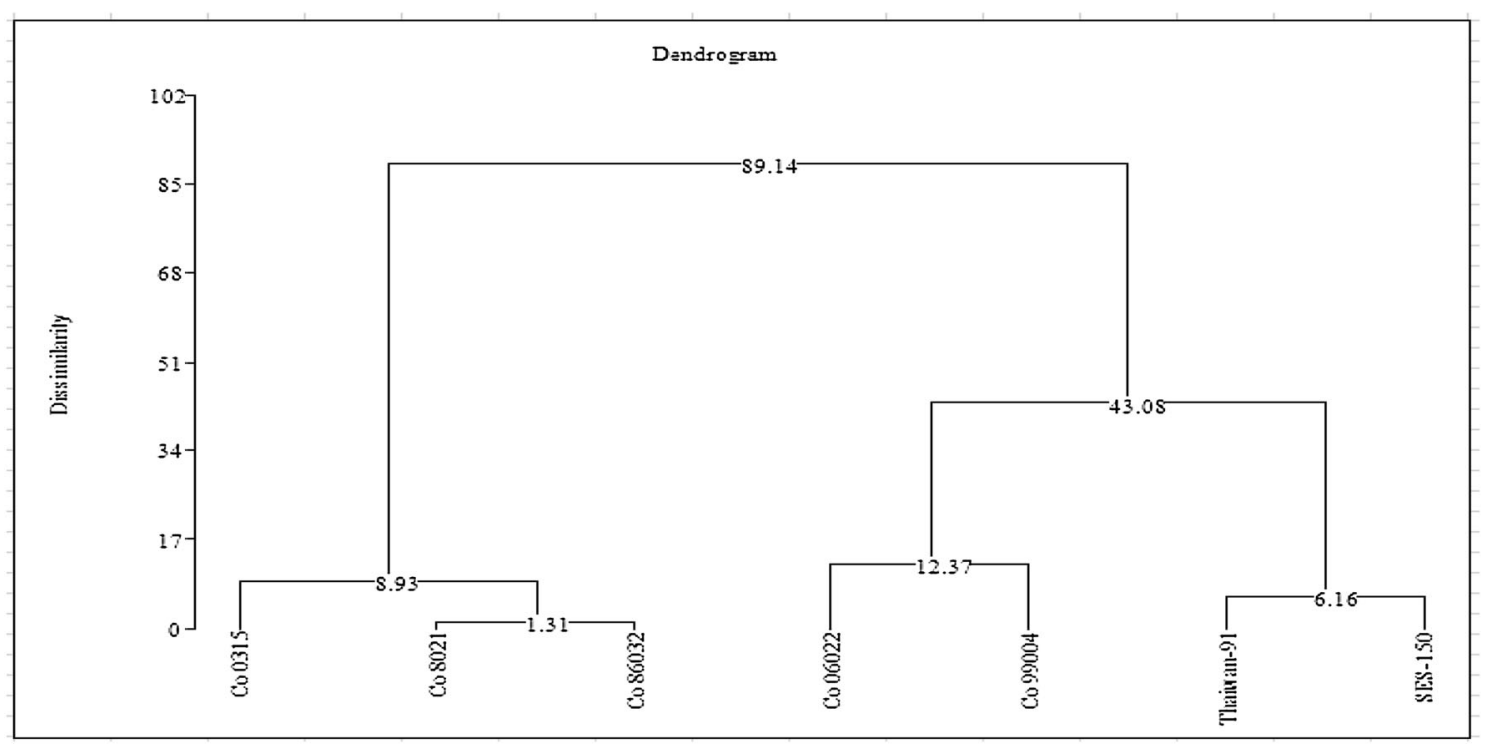

Fig. 2 Cluster analysis of the seven sugarcane genotypes based on physiological parameters in heat stress condition

Taiwan 96. Cluster II, 46.08 similarities with Cluster III and Cluster I, 89.14 similarities with cluster II and III. The higher similarity distance represents that the higher variation between the tolerant and sensitive genotypes.

\section{Conclusion}

In conclusion, high-temperature stress induced significant physiological and metabolic changes in all sugarcane genotypes at two stages of crop, however formative phase was found to more sensitive to high temperature as compared to grand growth phase. This study showed that physiological parameters such as chlorophyll content, CSI, antioxidant enzymes, enzymes of sucrose metabolism, soluble sugar content, proline content, total phenolics and leaf gas exchange parameters could be used as supplementary or alternative indicators for heat tolerance in sugarcane. Among the genotypes studied, the Co 99004 was found to be highly thermotolerant, as indicated by PCA and cluster analysis, which can be used as donor genotype for high-temperature tolerance. The results also 
suggest that the identified physiological traits can be used as heat tolerance index for screening larger population for thermotolerance.

Acknowledgements This work was funded by DST-SERB, New Delhi. The authors are thankful to the Director, ICAR-Sugarcane Breeding Institute, Coimbatore for providing necessary facility and support to carry out the research work successfully.

Open Access This article is distributed under the terms of the Creative Commons Attribution 4.0 International License (http://crea tivecommons.org/licenses/by/4.0/), which permits unrestricted use, distribution, and reproduction in any medium, provided you give appropriate credit to the original author(s) and the source, provide a link to the Creative Commons license, and indicate if changes were made.

\section{References}

Abbas, S. R., Shah, A. H., \& Rao, A. (2013). Classification of sugarcane genotypes based on heat stress and morphological parameters. Journal of Agricultural Studies, 1(2), 114-122.

Adams, W. W. I., Demig-Adams, B., Winter, K., \& Schreiber, U. (1990). The ratio of variable to maximum chlorophyll fluorescence from photosystem 11, measured in leaves at ambient temperature and at $77 \mathrm{~K}$, as an indicator of the photon yield of photosynthesis. Planta, 180, 166-174.

Anon, S., Fernandez, J. A., Franco, J. A., Torrecillas, A., Alarcon, J. J., \& SanchezBlanco, M. J. (2004). Effects of water stress and night temperature preconditioning on water relations and morphological and anatomical changes of Lotus creticus plants. Scientia Horticulturae, 101, 333-342.

Barrs, H. D., \& Weatherley, P. E. (1962). A re-examination of relative turgidity for estimating water deficits in leaves. Australian Journal of Biological Sciences, 15, 413-428.

Bates, L. S., Waldren, R. P., \& Teare, I. D. (1973). Rapid determination of proline for water stress studies. Plant and Soil, 39, 205-207.

Beauchamp, C., \& Fridovich, J. (1971). Superoxide dismutase: improved assay and an assay applicable to acrylamide gels. Analytical Biochemistry Experimental Medicine, 444, 274-287.

Blokhina, O., Eija, V., \& Kurt, V. F. (2003). Antioxidants, oxidative damage and oxygen deprivation stress: A review. Annals of Botany, 91, 179-194.

Briantais, J. M., Vernotte, C., Krause, G. H., \& Weiss, E. (1986). Chlorophyll a fluorescence of higher plants: Chloroplasts and leaves. In J. A. Govindjee \& D. C. Fork (Eds.), Light emission by plants and bacteria (pp. 539-583). Orlando: Academic Press.

Chaitanya, K. V., Sundar, D., Masilamani, S., \& Reddy, A. (2002). Variation in heat stress-induced antioxidant enzyme activities among three Mullberry cultivars. Plant Growth Regulation, 36, $175-180$

Chen, J., Xu, W., Velten, J., Xin, Z., \& Stout, J. (2012). Characterization of maize inbred lines for drought and heat tolerance. Journal of Soil and Water Conservation, 67, 354-364.

Cui, L., Li, J., Fan, Y., Xu, S., \& Zhang, Z. (2006). High temperature effects on photosynthesis, PSII functionality and antioxidant activity of two Festuca arundinacea cultivars with different heat susceptibility. Botanical Studies, 47, 61-69.

Deshmukh, P. S., Sairam, R. K., \& Shukla, D. S. (1991). Measurement of ion leakage as a screening technique for drought resistance in wheat genotypes. Indian Journal of Plant Physiology, 34, 89-91.
DuBois, M., Gilles, K. A., Hamilton, J. K., Rebers, P. A., \& Smith, F. (1956). Colorimetric method for determination of sugars and related substances. Analytical Chemistry, 28(3), 350-356.

Ebrahim, M. K., Zingsheim, O., \& EL-Shourbagy, M. N. (1998). Growth and sugar storage in sugarcane grown at temperatures below and above optimum. Journal of Plant Physiology, 153(5-6), 593-602.

Fardus, S., Wahid, A., Javed, F., \& Sadia, B. (2014). Changes in leaf phenolics concentrations determine the survival of evening primrose (Oenothera biensis) in various seasons. International Journal of Agriculture and Biology, 16, 819-824.

Farooq, M., Basra, S., Wahid, A., Cheema, Z., Cheema, M., \& Khaliq, A. (2008). Physiological role of exogenously applied glycinebetaine to improve drought tolerance in fine grainaromaticrice (Oryzasativa L.). Journal of Agronomy and Crop Science, 194, 325-333.

Foyer, C. F., \& Nector, G. (2000). Oxygen processing in photosynthesis regulation and signaling. New phytologist, 146, 359-388.

Gayler, K. R., \& Glasziou, K. T. (1972). Physiological functions of acid and neutral invertases in growth and sugar storage I sugarcane. Physiology Plant, 27, 25-31.

Gomathi, R., \& Kohila, S. (2016). Impact of temperature extremes on sugarcane growth and development. In Biotechnological and conventional tools for biotic and abiotic stresses management in sugarcane (pp. 162-170). Edited \& Compiled by Dr. Bakshi Ram, P. Govindaraj, A. Ramesh Sundar \& A. Bhaskaran and Published by Dr. Bakshi Ram, The Director, Sugarcane Breeding Institute.

Gomathi, R., Vasantha, S., Kohila, S., \& Lakshmi, K. (2017). Sucrose synthesis and accumulation in sugarcane in response to elevated temperature. In "International symposium on sugarcane research since Co 205: 100 years and beyond", held at Coimbatore, pp. 667-668.

Gomathi, R., Yukashini, K., Shiyamala, S., Vasantha, S., Suganya, A., \& Rakkiyappan, P. (2013). Induced response of sugarcane variety Co 86032 for thermotolerance. Sugar Tech, 15(1), 17-26.

Gosavi, G. U., Jadhav, A. S., Kale, A. A., Gadakh, S. R., Pawar, B. D., \& Chimote, V. P. (2014). Effect of heat stress on praline, chlorophyll content, heat shock proteins and antioxidant enzyme activity in sorghum (Sorghum bicolor) at seedlings stage. Indian Journal of Biotechnology, 13, 356-363.

Haba, P. D. L., Mata, L. D. L., Molina, E., \& Aguera, E. Y. (2013). High temperature promotes early senescence in primary leaves of sunflower (Helianthus annuus L.) plants. Canadian Journal of Plant Science, 94, 659-669.

Hageman, R. H., \& Hucklesby, D. P. (1971). Nitrate reductase in higher plants. In S. Pietro (Ed.), Methods in enzymology (pp. 491-503). New York: Academic Press.

Hall, A. E. (1992). Breeding for heat tolerance. Plant Breeding Reviews, 10, 129-168.

Hameed, A., Goher, M., \& Iqbal, N. (2012). Heat stress induced cell death, changes in antioxidants, lipid peroxidation and protease activity in wheat leaves. Journal of Plant Growth Regulation, 31, 283-291.

Harris, N., Foster, J. M., Kumar, A., Davies, H. V., Gebhardt, C., \& Wray, J. L. (2000). Two cDNAs representing alleles of the nitrate reductase gene of potato (Solanum tuberosum L. cv. Desiree): sequence analysis, genomic organization and expression. Journal of Experimental Botany, 51, 1017-1026.

Hasanuzzaman, M., Nahar, K., Alam, M. M., Roychowdhury, R., \& Fujita, M. (2013). Physiological, biochemical, and molecular mechanisms of heat stress tolerance in plants. International Journal of Molecular Sciences, 14, 9643-9684.

Hassanein, R. A., El-Khawas, S. A., \& Mohamed, A. M. K. (2012). Effect of heat shock on some biochemical and molecular criteria 
of fenugreek (Trigonella foenum-graceum L.). Journal of Medicinal Plants Research, 6(9), 782-1794.

Hatch, M. D., \& Glasziou, K. T. (1963). Sugar accumulation cycle in sugarcane II. Relationship of invertase activity to sugar content and growth rate in storage tissue of plants grown in controlled environments. Plant Physiology, 38, 338-343.

Hatfield, J. L., Boote, K. J., Kimball, B. A., Ziska, L. H., Izaurralde, R. C., Ort, D., et al. (2011). Climate impacts on agriculture: Implications for crop production. Agronomy Journal, 103, 351-370.

Hayat, S., Masood, A., Yusuf, M., Fariduddin, Q., \& Ahmad, A. (2009). Growth of Indian mustard (Brassica juncea L.) in response to salicylic acid under high temperature stress. Brazilian Journal of Plant Physiology, 21(3), 187-195.

Heath, R. L., \& Packer, L. (1968). Photoperoxidation in isolated chloroplasts. I. Kinetics and stoichiometry of fatty acid peroxidation. Archives of Biochemistry and Biophysics, 125, 189-198.

Hubbard, N. L., Huber, S. C., \& Pharr, D. M. (1989). Sucrose phosphate synthase and acid invertase as determinants of sucrose concentration in developing muskmelon (Cucumis mela L.) fruits. Plant Physiology, 91, 1527-1534.

Kaushal, N., Bhandari, K., Siddique, K. H. M., \& Nayyar, H. (2016). Food crops face rising temperatures: An overview of responses, adaptive mechanisms, and approaches to improve heat tolerance. Cogent Food \& Agriculture, 2, 1-42.

Koleyoras, A. S. (1958). A new method of determining drought resistance. Plant Physiology, 33(3), 232-233.

Krause, G. H., \& Weis, E. (1991). Chlorophyll fluorescence and photosynthesis: The basics. Annual Review of Plant Physiology and Plant Molecular Biology, 42, 313-349.

Kumar, R. R., Goswami, S., Sharma, S. K., Gadpayle, K. A., Kumar, N., Rai, G. K., et al. (2012a). Protection against heat stress in wheat involves change in cell membrane stability, antioxidant enzymes, osmolyte, $\mathrm{H}_{2} \mathrm{O}_{2}$ and transcript of heat shock protein. International Journal of Plant Physiology and Biochemistry, 4(4), 83-91.

Kumar, S., Gupta, D., \& Nayyar, H. (2012b). Comparative response of maize and rice genotypes to heat stress: Status of oxidative stress and antioxidants. Acta Physiologiae Plantarum, 34, 75-86.

Kumudini, S., Andrade, F. H., Boote, K. J., Brown, G. A., Dzotsi, K. A., Edmeades, G. O., et al. (2014). Predicting maize phenology: Intercomparison of functions for developmental response to temperature. Agronomy Journal, 106, 2087-2097.

Madamanchi, N. R., Yu, X., Doulis, A., Alsches, R. G., Hatzios, K. K., \& Crames, C. C. (1994). Acquired resistance to herbisides in pea cultivar through pretreatment with sulfur dioxide. Pesticide Biochemistry and Physiology, 48, 31-40.

Malick, C. P., \& Singh, M. B. (1980). Plant enzymology and histo enzymology (p. 286). New Delhi: Kalyani Publishers.

Meriga, B., Krishna Reddy, B., Rajender Rao, K., Ananda Reddy, L., \& Kavi Kishor, P. B. (2004). Aluminium-induced production of oxygen radicals, lipid peroxidation and DNA damage in seedlings of rice (Oryza sativa). Journal of Plant Physiology, $161,63-68$.

Miguel, A. R., Maria, M. R., Rosa, C., Nicolas, C., Juan, M. R., \& Luis, R. (2007). Sucrolytic activities in cherry tomato fruits in relation to temperature and solar radiation. Scientia Horticulturae, 113, 244-249.

Mohamed, H. I., \& Abdel-Hamid, A. M. E. (2013). Molecular and biochemical studies for heat tolerance on four cotton genotypes. Romanian Biotechnological Letters, 18(6), 8823-8831.

Morales, D., Rodríguez, P., Dell Amico, J., Nicolas, E., Torrecillas, A., \& Sánchez Blanco, M. J. (2003). High-temperature preconditioning and thermal shock imposition affects water relations, gas exchange and root hydraulic conductivity in tomato. Biologia Plantarum, 47, 203-208.

Oliveiram, J. G., Alves, P. L. C. A., \& Magalhaes, A. C. (2002). The effect of chilling on the photosynthetic activity in coffee (Coffea arabica L.) seedlings. The protective action of chloroplastid pigments. Brazilian Journal of Plant Physiology, 14, 95-104.

Peng, S., Garcia, F. V., Laza, R. C., \& Cassman, K. G. (1993). Adjustment for specific leaf weight improves chlorophyll meter's estimate of rice leaf nitrogen concentration. Agronomy Journal, 85, 987-990.

Preiss, J. (1982). Regulation of the biosynthesis and degradation of starch. Annual Review of Plant Physiology, 33, 431-454.

Putter, J. (1974). Peroxidases. In H. U. Bergmeyer (Ed.), Methods of enzymatic analysis (Vol. 10, pp. 685-690). Weinheim: Verlag Chemie.

Sikuku, P. A., Netondo, G. W., Onyango, J. C., \& Musyimi, D. M. (2010). Chlorophyll fluorescence, protein and chlorophyll content of three NERICA rainfed rice varieties under varying irrigation regimes. ARPN: Journal of Agricultural and Biological Science, 5, 19-25.

Sugio, A., Dreos, R., Aparicio, F., \& Maule, A. J. (2009). Thecytosolic protein response as a subcomponent of the wider heat shock response in Arabidopsis. Plant Cell, 21, 642-654.

Taulavuori, E., Hellstrom, E., Taulavuori, K., \& Laine, K. (2001). Comparison of two methods used to analyse lipid peroxidation from Vaccinium myrtillus (L.) during snow removal, reacclimation and cool acclimation. Journal of Experimental Botany, 52(365), 2375-2380.

Vacca, R. A., Pinto, M. C. D., Valenti, D., Passarella, S., Maria, E., \& Gara, L. D. (2004). Production of reactive oxygen species, alteration of cytosolic ascorbate peroxidase, and impairment of mitochondrial metabolism are early events in heat shock induced programmed cell death in tobacco Bright Yellow 2 cells. Plant Physiology, 134, 1100-1112.

Verma, V., Foullces, M. J., Worland, A. J., Sylvester-Bradley, R., Caligari, P. D. S., \& Snape, J. W. (2004). Mapping quantitative trait loci for flag leaf senescence as a yield determinant in winter wheat under optimal and drought-stressed environments. $E u$ phytica, 135, 255-263.

Wahid, A. (2007). Physiological implications of metabolite biosynthesis for net assimilation and heat-stress tolerance of sugarcane (Saccharum officinarum) sprouts. Journal of Plant Research, 120, 219-228.

Wahid, A., \& Ghazanfar, A. (2006). Possible involvement of some secondary metabolites in salt tolerance of sugarcane. Journal of Plant Physiology, 163, 723-730.

Witham, F. H., Blaydes, D. F., \& Devlin, R. M. (1971). Experiments in plant physiology (p. 245). New York: Van Nostrand.

Zeng, L., Shannon, M. C., \& Grieve, C. M. (2002). Evaluation of salt tolerance in rice genotypes by multiple agronomic parameters. Euphytica, 127, 235-245.

Zhao, D., Glaz, B., Irey, M. S., \& Hu, C. J. (2015). Sugarcane genotype variation in leaf photosynthesis properties and yield as affected by mill mud application. Agronomy Journal, 107(2), $506-514$.

Zhao, R., Guo, P. Y., Yuan, X. Y., Wang, J. Y., \& Han, M. Q. (2010). Effect of paraquaton the antioxidative enzyme activities and lipid peroxidation in opium poppy (Papver somniferum L.). Journal of Plant Diseases and Protection, 117, 55-59.

Zhao, D., \& Li, Y. R. (2015). Climate change and sugarcane production: Potential impact and mitigation strategies. International Journal of Agronomy. https://doi.org/10.1155/2015/ 547386. 